\title{
Training Design for the Competence of Ruminant Slaughterhouse Officers in Implementing Animal Welfare
}

\author{
Dwi Windiana \\ National Animal Health \\ Training Center \\ Cinagara, Bogor, Indonesia \\ dwindiana@gmail.com
}

\author{
Etih Sudarnika \\ Faculty of Veterinary Medicine \\ $I P B$ University \\ Bogor, Indonesia \\ etih.sudarnika@gmail.com
}

\author{
Fadjar Satrija \\ Faculty of Veterinary Medicine \\ $I P B$ University \\ Bogor, Indonesia \\ fsatrija@gmail.com
}

\begin{abstract}
The study aimed to evaluate the presence of training alumni and the existence of standard operating procedures (SOP) related to the improvement of competencies of cattle traders, slaughterers and stockmanship in implementing animal welfare at Ruminant Slaughter Houses (RSHs). The study was conducted at 16 RSHs in districts in 11 provinces from November 2014 to February 2015. Samples consisted of 38 stockmanship, 32 slaughterers, 32 cattle traders and 25 training alumni. Samples were segregated based on the dissemination of training results attended by training alumni and on the presence of slaughterhouse SOP. The study was performed by using survey, and data was collected by observation and interview using questionnaires. Data was analysed using $T$ test and descriptive statistic. The results showed that the percentage of animal welfare implementation at RSHs varied at the phases of activities. The highest percentage was in the slaughthering activities, amounted to $78.1 \%$, but in the animal knocking down activities, both by manual and stunning system, the percentage was low $(<50 \%)$. The RSHs that had training alumni, the competency improvement of stockmanship in implementing animal welfare has not yet been seen. This might be due to training alumni that had other position so they had less time for the RSHs progress and were unfocused as well as ineffective dissemination, coordination and cooperation. While the existence of SOP at RSHs showed that there was improvement of knowledge and skills of stockmanship in implementing animal welfare but not accompanied by the improvement in attitude. This condition need the addition of non-technical materials that can touch the realm of attitudes, communication, motivation, learning psychology, and mentoring teqniques. A special approach is needed in the development of animal welfare training design for RSHs staff, either in the form of Off or On The Job Training Program, or combining two programs.
\end{abstract}

Keywords-animal welfare, competence, slaughterhouse officers, training design

\section{INTRODUCTION}

The mandate of Law No. 18/2009 in connection with Law No. 41/2014 concerning Animal Husbandry and Animal Health that the Government, Provincial/ Regency/ Municipal Regional Governments are responsible for ensuring that meat in circulation meets safe, healthy, wholesome, and halal requirements. Meat to be circulated for public consumption is required to come from slaughtered animals from Ruminant Slaughterhouses
(RSHs) and animal slaughtering must meet the requirements of Islamic syariah, veterinary public health and animal welfare for animals that are required to be halal.

Human resources is the key determinant in implementing of animal welfare [1], therefore it can be said that animal suffering among others is due to the unawareness, inexperienced, less skilled, and less considerate officers in handling animals. However, [2] states that training provided for officers as well as monitoring of its implementation can achieve the desired animal welfare standards.

At the present conditions the human resources involved, handling officers, slaughterers and cattle traders at RSHs have not received much information about animal welfare and the implementation of animal welfare at all stages. Therefore, this assessment was conducted to get a picture of disparities between the existing and the standard competencies and to compile an Animal Welfare Training Design that will be developed based on the results of the assessment.

\section{MATERIALS AND METHODS}

The assessment was carried out in 16 Regency/ Municipal ruminant slaughterhouses spread across 11 provinces, from November 2014 to February 2015.

\section{A. Assessment Samples}

The assessment samples consisted of cattle traders, handling officers, slaughterers and training alumni. Furthermore, the samples were sorted out based on the dissemination of the results of animal welfare training followed by training alumni and the existence of Standard Operational Procedures (SOP) at RSHs. Samples consisted of 38 stockmanship, 32 slaughterers, 32 cattle traders and 25 training alumni. Training alumni is someone who attended the Animal Welfare Training on 15-21 June 2014 at National Animal Health Training Center Cinagara. The Standard Operational Procedures (SOPs) are written procedures that contain rules/ work steps prepared by the officers of RSHs in reflecting the best practices in the implementation of animal welfare.

\section{B. Assessment Method}

The assessment used the survey method. Data collection was carried out using a structured questionnaire that was 
filled through observation and interviews with all respondents. The analyses of data were performed descriptively and t-test was done to analyze the influence of dissemination by training alumni.

\section{RESULTS}

The influence of the existence of SOP on the competence of cattle traders, slaughterers and handling officers is shown in Table I.

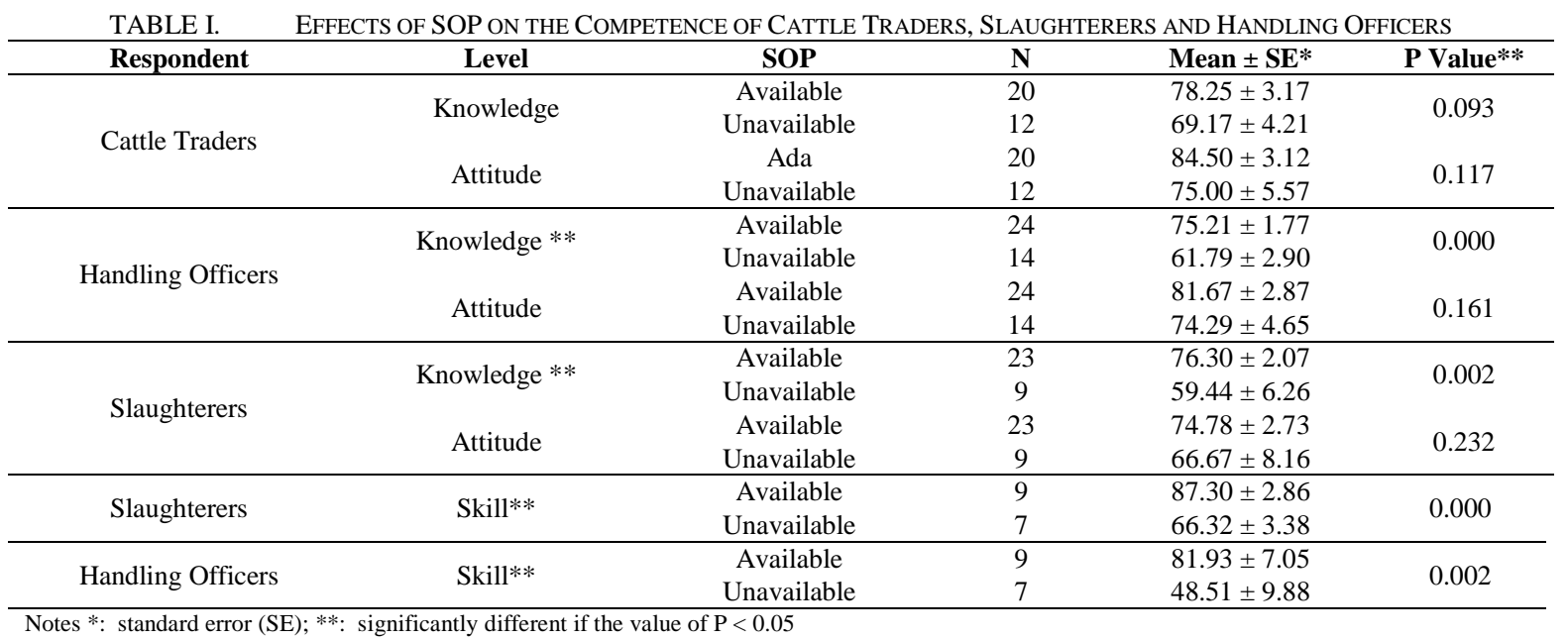

The effects of the SOP existence on the skills of slaughterers and handling officers at all stages of activities at RSHs are presented in Table II.

TABLE II. THE EFFeCts OF THE SOP EXISTENCE ON THE SKILLS OF SLAUGHTERERS AND HANDLING OfFICERS AT ACTIVITY STAGES AT RUMINANT SLAUGHTERHOUSES

\begin{tabular}{|c|c|c|c|c|c|}
\hline Respondent & $\begin{array}{l}\text { Activity stages at } \\
\text { ruminant } \\
\text { slaughterhouses }\end{array}$ & SOP & $\mathbf{N}$ & Mean $\pm \mathrm{SE}^{* *}$ & P Value* \\
\hline \multirow{9}{*}{$\begin{array}{c}\text { Handling } \\
\text { Officers }\end{array}$} & \multirow[t]{2}{*}{ Unloading } & Available & 9 & $88.90 \pm 5.20$ & \multirow{2}{*}{$0.001 *$} \\
\hline & & $\begin{array}{c}\text { Unavailable } \\
\text { Available }\end{array}$ & $\begin{array}{l}7 \\
9\end{array}$ & $\begin{array}{l}51.20 \pm 8.02 \\
8071+5.61\end{array}$ & \\
\hline & Lairaging & Unavailable & 7 & $39.10 \pm 14.52$ & $0.011^{*}$ \\
\hline & \multirow{2}{*}{ Herding } & Available & 9 & $79.49 \pm 6.40$ & \multirow{2}{*}{$0.022^{*}$} \\
\hline & & Unavailable & 7 & $45.06 \pm 12.83$ & \\
\hline & \multirow{2}{*}{ Manual Knocking* } & Available & 9 & $18.51 \pm 11.26$ & \multirow{2}{*}{$0.011^{*}$} \\
\hline & & Unavailable & 7 & $58.73 \pm 5.81$ & \\
\hline & \multirow{2}{*}{ Stunning* } & Available & 9 & $77.77 \pm 10.68$ & \multirow{2}{*}{$0.000^{*}$} \\
\hline & & Unavailable & 7 & $00.00 \pm 0.00$ & \\
\hline \multirow{2}{*}{ Slaughterers } & \multirow{2}{*}{ Slaughtering* } & Available & 9 & $87.30 \pm 2.86$ & \multirow{2}{*}{$0.000 *$} \\
\hline & & Unavailable & 7 & $66.33 \pm 3.39$ & \\
\hline
\end{tabular}

To find out in which stages the existence of SOP affects the skills of handling officers and slaughterers in implementing animal welfare at ruminant slaughterhouses is presented in Table III.

TABLE III. EFFECT OF DisSEMINATION By TRAINING ALUMNI ON THE SKILLS OF HANDLING OFFICERS AND SLAUGHTERERS DURING THE ACTIVITY STAGES AT RUMinANT SLAUGHTERHOUSES

\begin{tabular}{|c|c|c|c|c|c|}
\hline Respondent & $\begin{array}{c}\text { Activity Stages at } \\
\text { RSHs }\end{array}$ & $\begin{array}{l}\text { Training } \\
\text { Alumni }\end{array}$ & $\mathbf{N}$ & Mean \pm SE** & P Value* \\
\hline \multirow{5}{*}{$\begin{array}{l}\text { Handling } \\
\text { Officers }\end{array}$} & Unloading & $\begin{array}{c}\text { Available } \\
\text { Unavailable }\end{array}$ & $\begin{array}{l}8 \\
8\end{array}$ & $\begin{array}{c}80.21 \pm 7.86 \\
64.60 \pm 10.18\end{array}$ & 0.245 \\
\hline & Lairaging & $\begin{array}{c}\text { Available } \\
\text { Unavailable }\end{array}$ & $\begin{array}{l}8 \\
8\end{array}$ & $\begin{array}{l}65.80 \pm 10.19 \\
59.21 \pm 14.61\end{array}$ & 0.717 \\
\hline & Herding & $\begin{array}{c}\text { Available } \\
\text { Unavailable }\end{array}$ & $\begin{array}{l}8 \\
8\end{array}$ & $\begin{array}{c}76.92 \pm 5.44 \\
51.94 \pm 13.62\end{array}$ & 0.110 \\
\hline & Manual Knocking & $\begin{array}{c}\text { Available } \\
\text { Unavailable }\end{array}$ & $\begin{array}{l}8 \\
8\end{array}$ & $\begin{array}{l}31.95 \pm 13.02 \\
40.26 \pm 11.30\end{array}$ & 0.637 \\
\hline & Stunning & $\begin{array}{c}\text { Available } \\
\text { Unavailable }\end{array}$ & $\begin{array}{l}8 \\
8 \\
\end{array}$ & $\begin{array}{l}51.91 \pm 15.84 \\
35.58 \pm 17.38 \\
\end{array}$ & 0.499 \\
\hline Slaughterers & Slaughtering & $\begin{array}{c}\text { Available } \\
\text { Unavailable }\end{array}$ & $\begin{array}{l}8 \\
8\end{array}$ & $\begin{array}{l}82.15 \pm 3.82 \\
74.10 \pm 5.56\end{array}$ & 0.252 \\
\hline
\end{tabular}


The suggestions of training alumni on the application of teaching methods in Animal Welfare Training is presented in Table IV.

TABLE IV. Training ALUMni SugGestions on the APPLICATION OF TEACHING Methods

\begin{tabular}{|c|c|c|c|c|}
\hline \multirow[b]{2}{*}{ No } & \multirow[b]{2}{*}{ Subjects } & \multirow[b]{2}{*}{ Applied Methods } & \multicolumn{2}{|r|}{ Self Assessment } \\
\hline & & & $\begin{array}{l}\text { Suitabi- } \\
\text { lity }\end{array}$ & Suggestions \\
\hline 1. & $\begin{array}{l}\text { Policies on Veterinary Public Health and } \\
\text { Animal Welfare }\end{array}$ & Lecture, Discussion & $\sqrt{ }$ & More discussion \\
\hline 2. & $\begin{array}{l}\text { Ethics and Morals in the Application of } \\
\text { Animal Welfare }\end{array}$ & Lecture, Discussion & $\sqrt{ }$ & More discussion \\
\hline 3. & Livestock Behavior & Lecture, Discussion & $\sqrt{ }$ & Practical Work \\
\hline 4. & $\begin{array}{l}\text { Animal Welfare in Loading and } \\
\text { Transportation }\end{array}$ & $\begin{array}{l}\text { Lecture, Discussion, Case } \\
\text { Study, Comparative Study }\end{array}$ & $\sqrt{ }$ & More Comparative Study \\
\hline 5. & $\begin{array}{l}\text { Animal Welfare on Arrival at a } \\
\text { Slaughterhouse (unloading and lairaging) }\end{array}$ & $\begin{array}{l}\text { Lecture, Discussion, Case } \\
\text { Study, Comparative Study }\end{array}$ & $\sqrt{ }$ & More Comparative Study \\
\hline 6. & Animal welfare and meat quality & Lecture, Discussion & $\sqrt{ }$ & $\begin{array}{l}\text { Practical Work (meat } \\
\text { assessment) }\end{array}$ \\
\hline $7 .$. & $\begin{array}{l}\text { Restraining and Slaughtering Cattle without } \\
\text { Stunning }\end{array}$ & $\begin{array}{l}\text { Lecture, Discussion, Case } \\
\text { Study, Comparative Study }\end{array}$ & $\sqrt{ }$ & $\begin{array}{l}\text { More Comparative Study } \\
\text { to Slaughterhouses }\end{array}$ \\
\hline 8 & $\begin{array}{l}\text { Restraining and Slaughtering Cattle by } \\
\text { Stunning Processes }\end{array}$ & $\begin{array}{l}\text { Lecture, Discussion, Case } \\
\text { Study, Comparative Study }\end{array}$ & $\sqrt{ }$ & $\begin{array}{l}\text { More Comparative Study } \\
\text { to Ruminant } \\
\text { Slaughterhouses }\end{array}$ \\
\hline 9. & Halal Assurance System at Slaughterhouses & Lecture, Discussion & $\sqrt{ }$ & More discussion \\
\hline 10. & $\begin{array}{l}\text { Slaughterhouse Requirements and Meat } \\
\text { Handling Unit }\end{array}$ & Lecture, Discussion & $\sqrt{ }$ & More discussion \\
\hline 11 & $\begin{array}{l}\text { Seminar on Field Observation results at } \\
\text { practical sites }\end{array}$ & Group Presentation & $\sqrt{ }$ & Time is adequate \\
\hline
\end{tabular}

\section{DISCUSSION}

The results of the assessment in Table 1 show that the existence of SOP has a significant effect on the knowledge and skills of handling officers and slaughterers in implementing animal welfare at RSHs, while the influence of attitude has an upward trend but is not significantly different. This may occur because the handling officer and slaughterer only runs the existing SOP without being followed by understanding and appreciation on the benefits and uses of the SOP. Application of SOP at RSHs is related to slaughter of imported cattle, namely as a RSHs supply chain. The existence of a neglected SOP can result in a reduced supply of cattle or even not getting imported cattle, which can have an impact on the income of cattle traders, handling officers, and slaughterers.

Furthermore, from Table 2 it is illustrated that the effect of the SOP existence on the skills of slaughterers and handling officers at the stages of manual knocking, stunning and slaughtering is significantly different. This situation shows the possibility of ease for handling officers and slaughterers to follow the available SOP at the RSHs, in order to achieve good work results. Ease in following the SOP is possibly due to clear instructions/ guidelines, easy to implement in practice and the results can be quickly seen. In addition, there are demands from producer countries to implement SOP on animal welfare at every supply chain in RSHs.

There are three stages in the process of a person becoming skilled, namely understanding, comprehending and appreciating. The appreciation stage means that someone has made an evaluation on what has been understood with a positive conclusion and has a great motivation to practice it [3]. In the field, there are still many handling officers who smoke, pull tails to knock down cows, use objects/ electric shocks to herd animals, fixer the animals for too long before being slaughtered and skin the animal before it completely dies. Likewise, slaughterers who do not pay attention to hygiene and sanitation such the knife cleanliness, use unsuitable (too short) and unsharpened knives are still found. This illustration shows that the possibility of handling officers and slaughterers only carry out SOP solely for the continuation of slaughtering at the RSHs and ignore the attitude factor. This condition is in line with the results of the assessment that the existence of SOP has a significant effect on the knowledge and skills of handling officers and slaughterers but the attitude is stated not to be significantly different.

Table 3 illustrates that there is an effect of the dissemination of the results of animal welfare training from training alumni on the skills of slaughterers and handling officers at all stages of activities at RSHs, but it is not significantly different. This shows that the training alumni has possibly not done intensive assistance to officers. Some probable factors include training alumni that has double duties so that the time is not sufficient to provide assistance, is less communicative, is less motivating, encounters difficulties in mentoring, among others due to close family ties between a handling officer and a cattle trader and training alumni understanding that the existence of RSHs is only to facilitate the needs of the community, so that he only plays a passive role.

According to [4], leaning and learning process are aspects that are very closely related to training and development programs because in training and development there are teaching-learning processes. Learning is a relatively permanent change in behavior, cognitive/ thought, or affection/ emotion that occurs as a result of a person's interactions with the environment. Based on this, learning has an important aspect namely a learning focus which is a change and the change lasts a long time and undergoes processes. Based on the learning principles, training and development methods are generally categorized into two, 
namely the On-Job Training and the Off-Job Training Programs.

\section{REFERENCES}

[1] World Organization for Animal Health (OIE), "Slaugther in animal," in Terrestial animal health code, vol. I, 20th ed., 2011, pp. 332-355.
[2] D. M. Broom, "Animal welfare: concepts and measurement," Anim Sci., vol. 69, no. 10, pp. 4167-175, October 1991.

[3] I. Nuraeni and A. Suwandi, Manajemen Pelatihan. Jakarta: Universitas Terbuka Departemen Pendidikan Nasional, 2005.

[4] S. Mangkuprawira, "Manajemen sumber daya manusia strategik," 2nd ed., Bogor: Ghalia, 2011. 